\title{
Syngas for Methanol Production from Palm Oil Biomass Residues*
}

\author{
A. Bula ${ }^{1}$, J. Mendoza ${ }^{2}$, R. Gomez ${ }^{2}$ and M. Sanjuan ${ }^{1}$ \\ ${ }^{1}$ Department of Mechanical Engineering \\ Universidad del Norte, Barranquilla, Colombia \\ Km 5 Antigua Vía Puerto Colombia \\ ${ }^{2}$ Department of Mechanical Engineering \\ Universidad Pontificia Bolivariana - Sede Montería, Montería, Colombia \\ Corresponding author: A. Bula, e-mail: abula@uninorte.edu.co
}

\begin{abstract}
Biodiesel is produced from palm oil and methanol; this methanol could be obtained from gasification of the raw palm oil residual. The complete process includes: pre-treatment of the biomass, gasification, cleaning and conditioning of the gas and the final synthesis of methanol. A review of the gasification stage is carried out, a classification of the existent gasification reactors is presented and the characteristics of three types of gasifiers are detailed. Furthermore, a summary of certain chemical and physical requirements of the gas obtained by the gasification process are introduced. Some conditions are highlighted: the ratio hydrogen to carbon monoxide $\left(\mathrm{H}_{2} / \mathrm{CO}\right)$ must be close to two and, the quantities of diluted nitrogen, sulphur and water in the gas must be low. Keeping in mind these characteristics we proceeded to recommend the gasifier and gasification medium. Finally, a chemical equilibrium model is introduced to estimate the composition of the gas produced and to study the effect of the temperature and operation pressure in the quality of the gas produced. The gasification process considers a fluidized bed gasifier and the simulated results are compared with experimental data. The results showed that the simulation approach accurately represents the gasification process and allows considering the simulation for some other biomass residues.
\end{abstract}

Keywords: Palm oil biomass residual; gasification; methanol synthesis; syngas.

\section{Introduction}

Most of the oil used for the world biodiesel industry comes from plantations such as palm oil, soy, rape, and sunflower. The world palm oil production is close to $30.5 \times 106$ ton/year, where Malaysia, Indonesia, Nigeria, Thailand and Colombia are the main producers (Sumathi et al, 2007). In Colombia, more than 160x103 hectares are used to produce $3.24 \times 106$ tons of Fresh Fruit Bunches (FFB) yearly, which represents $709 \times 103$ tons of Empty Fruit Bunches (EFB), 431x103 tons of fiber, and 210x103 tons of shells (Fedepalma, 2006). The majority of the residues are used for composting, animal food, and to produce steam and energy (Yusoff, 2006).

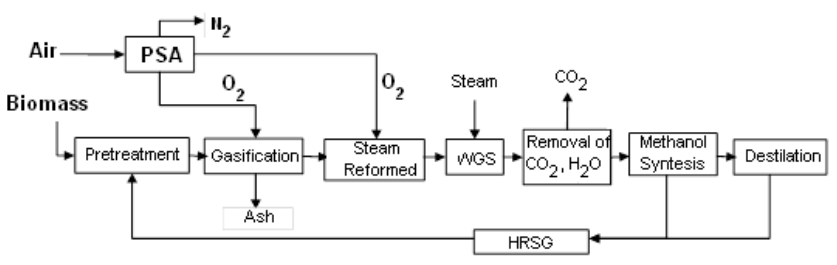

Figure 1. Process diagram for Methanol production from biomass.

In many cases, the usage of the residues is not very efficient due to the restrictions associated to the equipment and the biomass quality variation to obtain a fuel (Husain and Zaina, 2003), never the less, experimental results showing the products have been carried out (Yan et al.,
2005). Colombian biodiesel is produced from palm oil and methanol. The latest could be obtained from palm oil biomass residue gasification (Chew and Bhatia S, 2008). The syngas required to produce biomethanol could be attained from the process shown in Figure 1 (Minteer, 2006). This process includes pre-treatment for the biomass (drying and size reduction), gasification according to the biomass physical characteristics, cleaning of the gas produced, and the final methanol catalytic synthesis.

\section{Palm Oil Residues}

African oil palm (Elaeis guineensis) is grown for alimentary purposes. The amount of oil attained from this plant is five to seven times larger than some other oleaginous plants such as: peanut, sunflower, sesame, and soy. The oil is obtained from the pulp as well as from the seed. The biomass residues from the process are EFB (Empty fresh bunches), fiber and shells. The amount of each residue is presented in Table 1 (Arrieta et al, 2007).

Table 1. Biomass residues produced during the processing. of palm oil

\begin{tabular}{|c|c|c|c|}
\hline \multirow{2}{*}{ Mat } & \multicolumn{3}{|c|}{$\%$ ash function of Fresh Fruit Bunches } \\
\cline { 2 - 4 } & Min. & Max. & Average \\
\hline EFB & 17.7 & 26.1 & 21.9 \\
\hline Fiber & 11.6 & 15 & 13.3 \\
\hline Shells & 5 & 8 & 6.5 \\
\hline
\end{tabular}


The relevant analysis for the biomass gasification process is presented in Tables 2, 3, and 4, where the proximate, chemical composition and ultimate analysis are shown respectively.

Table 2. Palm Oil Biomass Proximate Analysis (dry base) and initial humidity content. (Quaak et al, 1999; U.S Department of Energy, 1988).

\begin{tabular}{|c|c|c|c|c|c|c|c|}
\hline Mat & $\begin{array}{c}\text { Energy } \\
(\mathrm{kJ} / \mathrm{Kg})\end{array}$ & $\begin{array}{c}\text { Volatile } \\
\text { Matter } \\
(\%)\end{array}$ & $\begin{array}{c}\text { Humidity } \\
\text { Residual } \\
\%\end{array}$ & $\begin{array}{c}\text { Ash } \\
\%\end{array}$ & $\begin{array}{c}\text { Carbon } \\
\text { Fixed } \\
\%\end{array}$ & $\begin{array}{c}\text { Sulfur } \\
\text { Total } \\
\%\end{array}$ & $\begin{array}{c}\text { Humidity } \\
\text { Initial } \\
\%\end{array}$ \\
\hline EFB & 19599 & 71.9 & 6.7 & 5.3 & 16.1 & 0.12 & 60 \\
\hline Fiber & 18711 & 70.7 & 7.4 & 3.3 & 18.6 & 0.15 & 39 \\
\hline Shell & 20490 & 71.2 & 7.4 & 2.1 & 19.3 & 0.08 & 19 \\
\hline
\end{tabular}

According to Table 2, and taking into consideration the manipulation required to process the different residues obtained from the palm, the biomass can be categorized for energy generation as shells, fiber and EFB.

Table 3. Palm Oil biomass chemical composition. (Chew and Bhatia, 2008 (1); Abdullah and Gerhauser, 2008 (2); Kelly-Yong and Lee, 2007(3)).

\begin{tabular}{|l|l|l|l|l|l|l|}
\hline \multirow{2}{*}{ Component } & \multicolumn{6}{|c|}{$(\%$ mass $)$} \\
\cline { 2 - 8 } & $\begin{array}{c}\text { EFB } \\
(2)\end{array}$ & $\begin{array}{c}\text { EFB } \\
(3)\end{array}$ & $\begin{array}{c}\text { Fiber } \\
(1)\end{array}$ & $\begin{array}{c}\text { Fiber } \\
(2)\end{array}$ & $\begin{array}{c}\text { Log } \\
(1)\end{array}$ & $\begin{array}{c}\text { Shell } \\
(2)\end{array}$ \\
\hline Ash & - & 1.6 & 4.89 & 3.5 & - & 1 \\
\hline Lignin & 18.1 & 22.1 & 24.89 & 27.7 & 20.3 & 50.7 \\
\hline Holocellulose & - & - & 52.05 & - & - & - \\
\hline Cellulose & 59.7 & 38.3 & - & 33.9 & 33.9 & 20.8 \\
\hline Hemicellulose & 22.1 & 35.3 & 18.2 & 26.1 & - & 22.7 \\
\hline Xylose & - & - & - & - & 16.8 & - \\
\hline Glucose & - & - & - & - & 29.0 & - \\
\hline Extracts & - & 2.7 & - & 6.9 & - & 4.8 \\
\hline
\end{tabular}

Table 4. Palm Oil Biomass Ultimate Analysis (dry base).

\begin{tabular}{|l|l|l|l|l|l|l|}
\hline \multirow{2}{*}{} & \multicolumn{5}{|c|}{ (\% dry base) } & \multicolumn{1}{l}{ LHV } \\
\cline { 2 - 6 } & $\mathrm{C}$ & $\mathrm{H}$ & $\mathrm{N}$ & $\mathrm{S}$ & $\mathrm{O}$ & $\mathrm{kJ} / \mathrm{Kg}$ \\
\hline EFB & 48.79 & 7.33 & 0.00 & 0.68 & 36.30 & 18960 \\
\hline Fiber & 50.27 & 7.07 & 0.42 & 0.63 & 36.28 & 20640 \\
\hline Shell & 53.78 & 7.2 & 0.00 & 0.51 & 36.30 & 22140 \\
\hline
\end{tabular}

\section{Syngas Production from Biomass Gasification}

During the gasification process, the solid and liquid material is converted through a partial oxidation into a gas called syngas. This syngas is mainly composed of hydrogen (H2) and carbon monoxide (CO). It also includes carbon dioxide $(\mathrm{CO} 2)$, water vapor $(\mathrm{H} 2 \mathrm{O})$, methane $(\mathrm{CH} 4)$, heavy hydrocarbons $(\mathrm{C} 2+)$ and nitrogen (N2) (Ciferno and Marano; 2002, Hernandez et al, 2010a; Hernandez et al, 2010b; Cujia and Bula, 2010). The reactions take place at temperatures between $500^{\circ} \mathrm{C}$ to $1400^{\circ} \mathrm{C}$, and the pressure required varies from atmospheric up to 33 bars. The oxidizer can be air, pure oxygen, water vapor or a mixture (Saxena, 2008). The syngas obtained from a gasification process using air presents low energy content, from 4 to 6 $\mathrm{MJ} / \mathrm{m} 3$. When oxygen is used, the syngas presents high concentration of hydrogen and carbon monoxide, and the energy content reaches 10 to $20 \mathrm{MJ} / \mathrm{m} 3$. The use of water vapor tends to produce higher energy content in the syngas (Bula et al, 2011) and increases the hydrogen generation as well.

\subsection{Gasification Technology}

A great variety of gasifiers are presented in the literature (Ciferno and Marano, 2002; Saxena, 2008; BTG, 2008; Basu, 2006; Higman and van der Burgt, 2003). These gasifiers can be classified according to different operation parameters as shown in Table 5.

Table 5. Gasifiers classification parameters

\begin{tabular}{|c|c|c|c|c|c|}
\hline Operation & Oxidizer & Pressure & $\begin{array}{l}\text { Heating } \\
\text { Mode }\end{array}$ & $\begin{array}{l}\text { Contact } \\
\text { between the } \\
\text { oxidizer and } \\
\text { the fuel }\end{array}$ & $\begin{array}{l}\text { Energy } \\
\text { content }\end{array}$ \\
\hline \multirow[t]{2}{*}{ 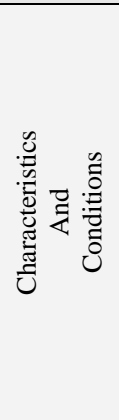 } & $\begin{array}{l}\text { Air. The } \\
\text { syngas } \\
\text { contains } \\
\text { up to 50\% } \\
\text { of } \\
\text { nitrogen. } \\
\\
\text { Water } \\
\text { vapor }\end{array}$ & $\begin{array}{l}\text { Atmospheric } \\
\text { pressure. }\end{array}$ & $\begin{array}{l}\text { Direct } \\
\text { heating. }\end{array}$ & $\begin{array}{l}\text { Drag flow. } \\
\text { Fluidized bed } \\
\text { (circulating } \\
\text { and bubbles) } \\
\text { Fixed bed. } \\
\text { (Updraft, } \\
\text { downdraft, } \\
\text { and cross } \\
\text { flow) }\end{array}$ & $\begin{array}{l}\text { Low energy } \\
\text { content, } 3 \text { to } \\
5 \mathrm{MJ} / \mathrm{Nm}^{3} \\
\text { Low energy } \\
\text { content, } 5 \text { to } \\
10 \mathrm{MJ} / \mathrm{Nm}^{3} \\
\\
\text { High energy } \\
\text { content } 10 \text { to } \\
40 \mathrm{MJ} / \mathrm{Nm}^{3}\end{array}$ \\
\hline & Oxygen & & & & \\
\hline
\end{tabular}

\subsection{Gasification Stages}

In a gasification process, four main physicochemical processes can occur simultaneously in different regions of the gasifier at certain temperatures (Demirbas, 2002), these are:

- Drying: $\left(\mathrm{T}>150{ }^{\circ} \mathrm{C}\right)$,

- Pyrolysis o devolatilization: $\left(150-700{ }^{\circ} \mathrm{C}\right)$,

- Oxidation: $\left(700-1500^{\circ} \mathrm{C}\right)$ and

- Reduction: $\left(800-1100{ }^{\circ} \mathrm{C}\right)$.

During the drying, the humidity is removed from the solid by evaporation. In the pyrolysis, a breakdown takes place because the water vapor, organic liquids and non condensing gases separate from the fixed carbon. In the oxidation, the fuel reacts with the oxygen to release heat, while in the reduction the energy is absorbed by the gas.

\subsubsection{Pyrolysis and Devolatilization}

This stage begins at a temperature close to $350^{\circ} \mathrm{C}$. When the temperature reaches $700^{\circ} \mathrm{C}$, the process accelerates and a series of complex chemical and physical reactions take place. The composition of the products generated during the devolatilization is function of the temperature, pressure, and composition of the biomass. The pyrolysis process can be represented by the following general reaction (R.1):

$$
\text { Biomass + Heat } \rightarrow \text { Gases + Liquid or Vapors }
$$

The products from this reaction can be grouped as: 1) gases such as $\mathrm{H}_{2}, \mathrm{CO}, \mathrm{CO}_{2}, \mathrm{H}_{2} \mathrm{O}, \mathrm{CH}_{4}, 2$ ) tars from long chain hydrocarbons and inorganic molecules, 3) carbon as a solid residual.

\subsubsection{Oxidation}

In the direct heating gasifiers, the oxidation reaction provides the heat required in the endothermic reactions. The oxygen supplied to the gasifier reacts with the fuel, resulting in $\mathrm{CO} 2$ (R.2) and $\mathrm{H} 2 \mathrm{O}$ (R.3).

$$
\mathrm{C}+\mathrm{O}_{2} \leftrightarrow \mathrm{CO}_{2}+393.77 \frac{\mathrm{kJ}}{\text { mol carbon }}
$$




$$
\mathrm{H}_{2}+\frac{1}{2} \mathrm{O}_{2} \leftrightarrow \mathrm{H}_{2} \mathrm{O}+742.00 \frac{\mathrm{kJ}}{\text { mol carbon }}
$$

\subsubsection{Gasification}

The gasification involves a series of endothermic reactions which are stimulated by the heat released in the previous exothermic reactions. These reactions transform the biomass into a flammable gas. The most important reactions are the following.

Water - Gas: this reaction involves the carbon partial oxidation due to the water vapor produced during the drying process, the humidity introduced with the air, the biomass break down or the steam supplied to the gasifier. The water vapor reacts with the carbon according to the following heterogeneous reaction (R.4):

$$
\mathrm{C}+\mathrm{H}_{2} \mathrm{O} \leftrightarrow \mathrm{H}_{2}+\mathrm{CO}-131.38 \frac{k J}{\text { mol carbon }}
$$

$\mathrm{CO}_{2}$ Reduction: the carbon dioxide produced in the gasifier can react with the carbon to produce $\mathrm{CO}$ according to the following endothermic reaction (R.5):

$$
\mathrm{CO}_{2}+\mathrm{C} \leftrightarrow 2 \mathrm{CO}-172.58 \frac{\mathrm{kJ}}{\text { mol carbon }}
$$

Water Gas Shift Reaction: the water vapor reduction generated by the carbon monoxide is advantageous due to the production of hydrogen. The exothermic reaction governing this process is the following: (R.6):

$$
\mathrm{CO}+\mathrm{H}_{2} \mathrm{O} \leftrightarrow \mathrm{CO}_{2}+\mathrm{H}_{2}-41.98 \frac{k J}{\text { mol carbon }}
$$

This reaction increases the $\mathrm{H} 2 / \mathrm{CO}$ ratio in the gas produced, and it is used in the manufacturing of syngas.

Methane Reaction: methane is obtained in the gasifier through the following reaction (R.7):

$$
\mathrm{C}+2 \mathrm{H}_{2} \leftrightarrow \mathrm{CH}_{4}+74.90 \frac{\mathrm{kJ}}{\text { mol carbon }}
$$

This reaction can be accelerated using catalysts based on Nickel, and working at temperatures around $1100^{\circ} \mathrm{C}$ and pressure ranging from 6 to 8 bars.

The composition of the gas attained from gasification varies depending on the biomass characteristics, the gasification media, operation pressure, temperature, humidity content and type of gasifier (Kirubakaran et al, 2007; Li and Grace, 2003). Although it is difficult to predict the exact composition of the gas produced, chemical equilibrium conditions can help to understand the behavior and performance of the gasifiers under certain operational conditions.

\section{Syngas Potential Uses}

Figure 2 briefly shows different paths that can be considered for syngas usage. Table 6 shows the syngas requirements for two specific applications (Chew and Bhatia, 2008; Ciferno and Marano, 2002; Kirubakaran et al, 2007). It is necessary to highlight that this study focuses in the gasification of palm oil residues to obtain a syngas adequate for liquid fuels production, such as methanol.

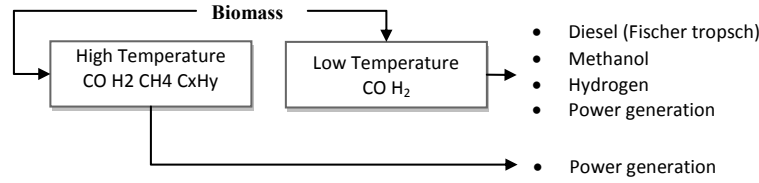

Figure 2. Possible paths for syngas usage.

According to the literature and experimental works carried out, the following aspects are considered relevant for methanol production form syngas:

- It is convenient to have a fluidized bed gasifier using oxygen and water vapor as oxidant agents. This avoid the presence of nitrogen in the products and save time and energy in the cleaning process. Furthermore, the use of oxygen allows a gas with a better energy content (10$15 \mathrm{MJ} / \mathrm{Nm} 3$ ) (Saxena, 2008)

- Even though the gasification process with air is widely used, it produces a syngas with a low energy content, higher humidity, tar and hydrocarbons. The amount of impurities in the syngas is greater, increasing the cleaning process cost.

- The use of steam may cause corrosion in the gasifier, but it is preferable to use it due to a greater conversion of the carbon present in the biomass. Furthermore, the water vapor addition produces tars which are easily catalytically transformed (Milne and Evans, 1998)

- The operation at high pressure reduces tar and long chain hydrocarbons production

- Generally, a single gasification stage does not produce a gas with the required $\mathrm{H} 2$ content, and it is necessary to introduce "water gas shift reactors" in order to adjust the $\mathrm{H}_{2} / \mathrm{CO}$ ratio (Demirbas, 2002).

Table 6 presents the chemical composition and physical conditions required by the syngas in order to attain methanol (Ciferno and Marano, 2002; Demirbas, 2002). It is noticed that the $(\mathrm{H} 2 / \mathrm{CO})$ molar ratio must be close to 2 , the diluted quantities of nitrogen, sulfur and water must be low. Nevertheless, these requirements must not be considered as conclusive and final rules.

Table 6. Syngas requirements for methanol production.

\begin{tabular}{|l|l|}
\hline Syngas & Methanol \\
\hline $\mathrm{H}_{2} / \mathrm{CO}$ & Close to 2 \\
\hline $\mathrm{CO}_{2}$ & Low \\
\hline $\mathrm{Hydrocarbons}$ & Low \\
\hline $\mathrm{N}_{2}$ & Low \\
\hline $\mathrm{H}_{2} \mathrm{O}$ & Low \\
\hline Contaminants & $<1$ ppm sulfur. Low particles \\
\hline Energy Content & Non important \\
\hline Pressure, bar & Aprox. 50 (liquid phase) 140 (vapor phase) \\
\hline Temperature ${ }^{\circ} \mathrm{C}$ & $100-200$ \\
\hline
\end{tabular}

\section{Results and Discussion}

\subsection{Syngas Composition Estimation and Effect of some Operational Parameters}

The equilibrium composition for the gas attained in the gasifier can be estimated using chemical equilibrium conditions along with the ultimate analysis and parameters such as temperature and pressure. The composition also depends on the oxidant introduced per unit of solid fuel. A chemical equilibrium model is presented in order to estimate the composition of the syngas produced. The sulfur introduced by the biomass is neglected. Let consider the following notation: 
F: $\quad$ Dry base biomass supplied, $\mathrm{kg} \mathrm{db}$

W: Biomass humidity, $\mathrm{Kg} \mathrm{H}_{2} \mathrm{O} / \mathrm{Kg} \mathrm{db}$

S: Water vapor per kg of dry biomass, $\mathrm{Kg} \mathrm{H}_{2} \mathrm{O} / \mathrm{Kg} \mathrm{db}$

A: Dry air per kg of dry biomass, $\mathrm{Kg}$ Air/ $\mathrm{Kg} \mathrm{db}$

$\mathrm{Xi}$ : Mass fraction, $\mathrm{Kg} \mathrm{i} / \mathrm{Kg} \mathrm{db}$

yi: Molar fraction, Kgmol i/Kgmol gas

The molar and equilibrium equations are the following:

Molar balance for Carbon C

$$
F\left(\frac{X_{C}}{12}\right)=n_{O}\left(y^{C O}+y^{C O_{2}}+y^{C H_{4}}\right)
$$

Molar balance for Hydrogen $\mathrm{H}_{2}$

$$
F\left(\frac{X_{H}}{2}+\frac{S}{18}+\frac{W}{18}\right)=n_{O}\left(y^{H_{2}}+y^{H_{2} O}+y^{C H_{4}}\right)
$$

Molar balance for $\mathrm{O}_{2}$

$$
\begin{aligned}
F\left(\frac{X_{O}}{32}+\frac{w}{2 * 18}+\frac{s}{2 * 18}+\frac{A X_{O_{2}}}{32}\right) & = \\
& n_{O}\left(y^{C O_{2}}+\frac{1}{2} y^{C O}+\frac{1}{2} y^{H_{2} O}\right)
\end{aligned}
$$

Where $\mathrm{X}_{\mathrm{O} 2}$ is the mass fraction for the oxygen, $\mathrm{O}_{2}$, in the dry air.

Molar balance for $\mathrm{N}_{2}$

$F\left(\frac{X_{N}}{2 * 14}+\frac{A X_{N_{2}}}{28}\right)=n_{O}\left(y^{N_{2}}\right)$

Where $X_{N 2}$ is the mass fraction for the nitrogen, $N_{2}$, in the dry air

Sum of Molar fractions

$$
y^{\mathrm{CO}}+y^{\mathrm{H}_{2}}+y^{\mathrm{CO}_{2}}+y^{\mathrm{CH}_{4}}+y^{\mathrm{H}_{2} \mathrm{O}}+y^{\mathrm{N}_{2}}=1
$$

Chemical equilibrium for the reaction

$$
\begin{aligned}
& e^{\left\lceil\frac{\left(g_{C}^{*}+g_{H_{2}}^{*}-g_{C H_{4}}^{*}\right)}{R T}\right]}=\frac{x_{C H_{4}}}{x_{H_{2}}^{2}}\left(\frac{P_{0}}{P_{g a s}}\right) \\
& e^{\left\lceil\frac{\left(g_{C}^{*}+g_{\left.\mathrm{H}_{2} \mathrm{O}^{-} g_{\mathrm{CO}}^{*}-g_{\mathrm{H}_{2}}^{*}\right)}^{R T}\right.}{R T}\right.}=\frac{x_{\mathrm{CO}} x_{\mathrm{H}_{2}}}{x_{\mathrm{H}_{2} \mathrm{O}}}\left(\frac{P_{g a s}}{P_{0}}\right) \\
& e^{\left\lceil\frac{\left(g_{C}^{*}+g_{C O_{2}}^{*}-2 g_{C O}^{*}\right)}{R T}\right\rceil}=\frac{x_{C O}^{2}}{x_{C O_{2}}^{2}}\left(\frac{P_{g a s}}{P_{0}}\right) \\
& g_{c}^{*}=\left(g_{f}^{0}\right)_{i}+\left(h_{T}-h_{T_{0}}\right)_{i}-T\left(S_{T}\right)_{i}+T_{O}\left(S_{T_{0}}^{0}\right)_{i}
\end{aligned}
$$

The solution of this system provides the concentration of each component in the syngas. Table 7 presents the parameters and the equilibrium constants (Basu, 2006) used in the solution of the model. The amount of air introduced per unit of dry biomass was obtained using an Equivalence Ratio (ER) of 0.25. ER is defined as the amount of air introduced divided by the amount of air required for a stoichiometric combustion reaction. The results obtained for the syngas composition are presented in Figure 3 and 4.
Table 7. Parameters used for the model

\begin{tabular}{|c|c|c|}
\hline Model Parameter & Value & Units \\
\hline $\mathrm{F}$ & 1 & $\mathrm{Kg}$ \\
\hline \multirow{3}{*}{$(\mathrm{ER}=0.25)$} & Fiber $=1.669$ & \multirow{3}{*}{$\mathrm{Kg} \mathrm{Air} / \mathrm{Kg}$} \\
\cline { 2 - 3 } & $\mathrm{EFB}=1.650$ & \multirow{2}{*}{ Shell $=1.780$} \\
\hline $\mathrm{P}$ & $1 \mathrm{a} 30$ & Atm \\
\hline
\end{tabular}

\subsection{Syngas Composition}

The results obtained from the simulation includes the concentration for methane $(\mathrm{CH} 4)$, carbon monoxide $(\mathrm{CO})$, hydrogen $(\mathrm{H} 2)$, and hydrogen/carbon monoxide $(\mathrm{H} 2 / \mathrm{CO})$ ratio. These results are compared with the values attained by Yan et al. (2005) for palm oil residues.

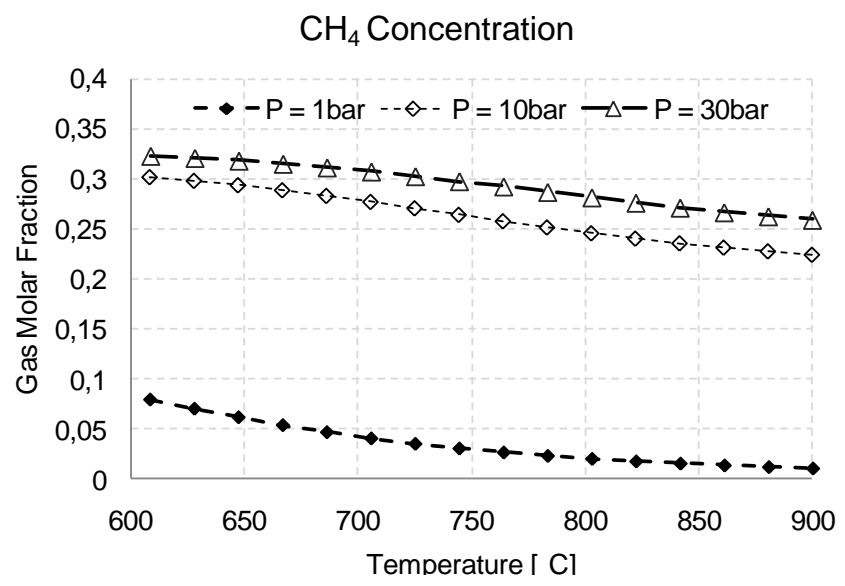

Figure 3. Methane molar fraction.

Figure 3 presents the results obtained for methane from the simulation. It shows that methane production decreases as temperature increases for the different pressures considered. It is also noticed that the maximum to minimum molar fraction difference remains quite constant at 0.07 for the different pressure values considered. The effect of the pressure is very significant, increasing the amount of methane produced as this variable increases. Methane molar fraction at 1 bar ranges from 0.08 to 0.01 , while at 30 bars, ranges from 0.32 to 0.26 . When methane simulated production for 1 bar is compared, at $600^{\circ} \mathrm{C}$ and $900^{\circ} \mathrm{C}$, Yan et al (2005) present the following values: 0.08 and 0.01 , which are the same values attained in this paper.

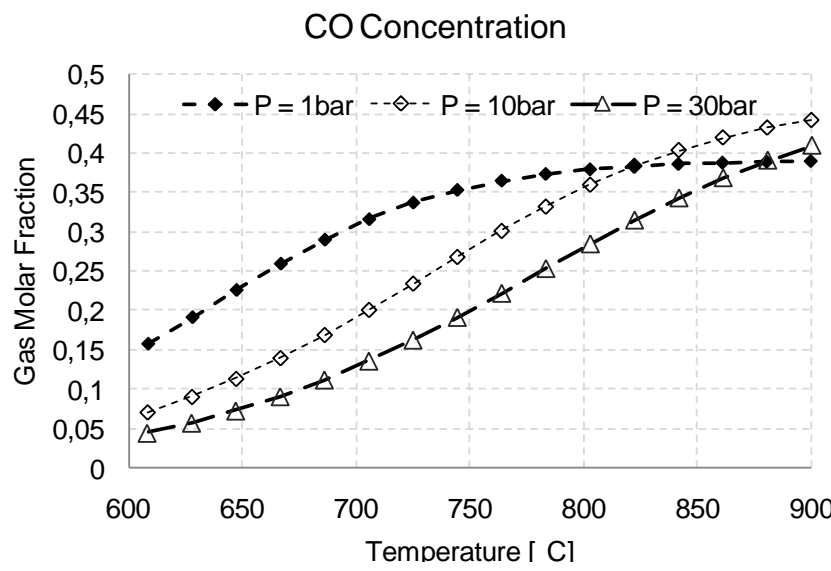

Figure 4. Carbon monoxide molar fraction.

The simulation results for carbon monoxide are presented in Figure 4. It is noticed that carbon monoxide production increases as temperature increases for the three 
different pressures considered. Furthermore, it is also noticed that the concentration values decrease as pressure increases, never the less, this effect is more noticeable for temperatures below $800^{\circ} \mathrm{C}$. For temperatures higher than $800^{\circ} \mathrm{C}$, the curve for 1 bar presents a point of inflexion, meaning that it reaches a maximum. For the other two pressures, this value was not reached but the curves trends tend to indicate that. When carbon monoxide results for 1 bar are compared, at $600^{\circ} \mathrm{C}$ and $900^{\circ} \mathrm{C}$, Yan et al (2005) present the following values: 0.07 and 0.32 , while the simulated results are 0.12 and 0.34 respectively.

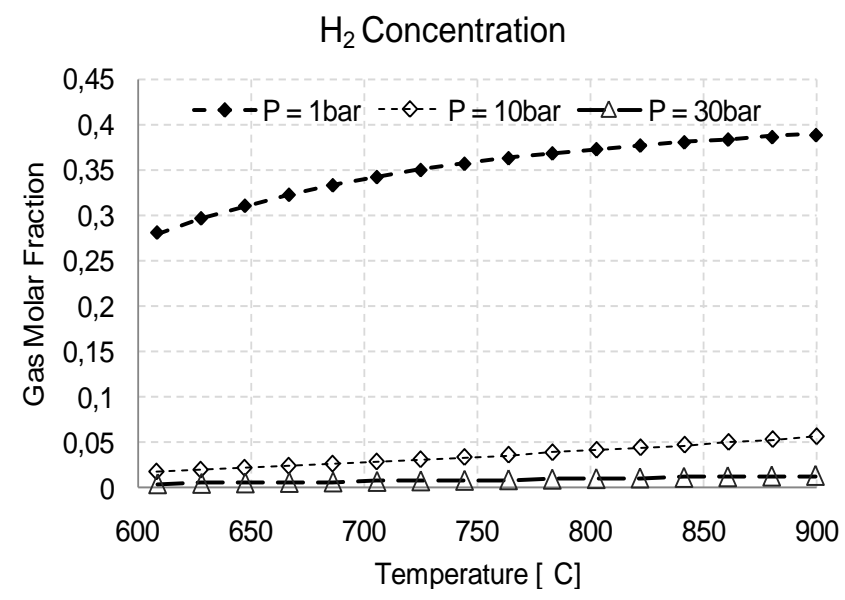

Figure 5. Hydrogen molar fraction.

Figure 5 presents hydrogen molar concentration. It is noticed that hydrogen production increases as temperature increases for the three different pressures considered. It is also noticed that the concentration values decrease as pressure increases. When hydrogen results for 1 bar are compared, at $600^{\circ} \mathrm{C}$ and $900^{\circ} \mathrm{C}$, Yan et al. (2005) present the following values: 0.28 and 0.41 , while the simulated results are 0.28 and 0.39 respectively.

Figure 6 presents the results obtained for water vapour from the simulation. It shows that water vapour production decreases as temperature increases for the different pressures considered. Furthermore, the concentration also decreases as pressure is increased for the process. When methane simulated production for 1 bar is compared, at $600^{\circ} \mathrm{C}$ and $900^{\circ} \mathrm{C}$, Yan et al (2005) present the following values: 0.12 and 0.01 , while the simulated results are 0.09 and 0.007 respectively.

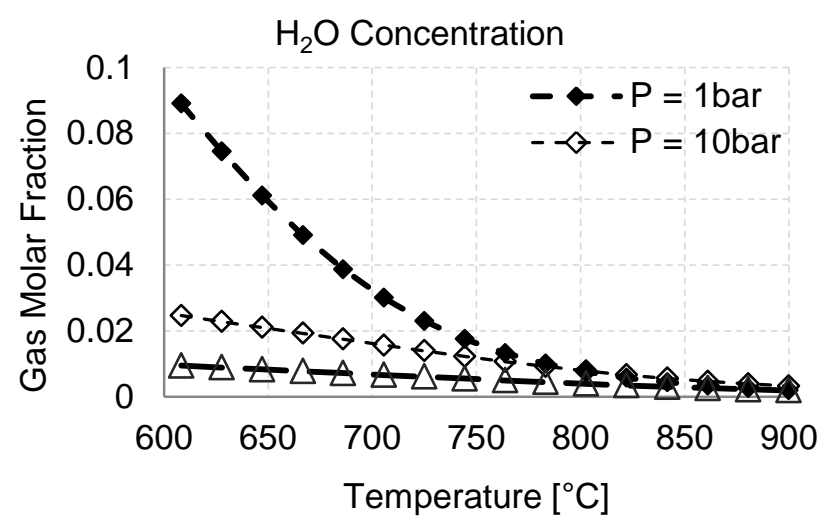

Figure 6. Water vapour concentration.

An important factor to be considered in the biomass gasification, especially when the syngas is produced to be used for methanol or some other hydrocarbons, is the hydrogen/carbon monoxide ratio. In this case, the ratio decreases as temperature as well as pressure increases. It is important to notice that this ratio remains almost constant for temperature values over $750^{\circ} \mathrm{C}$.

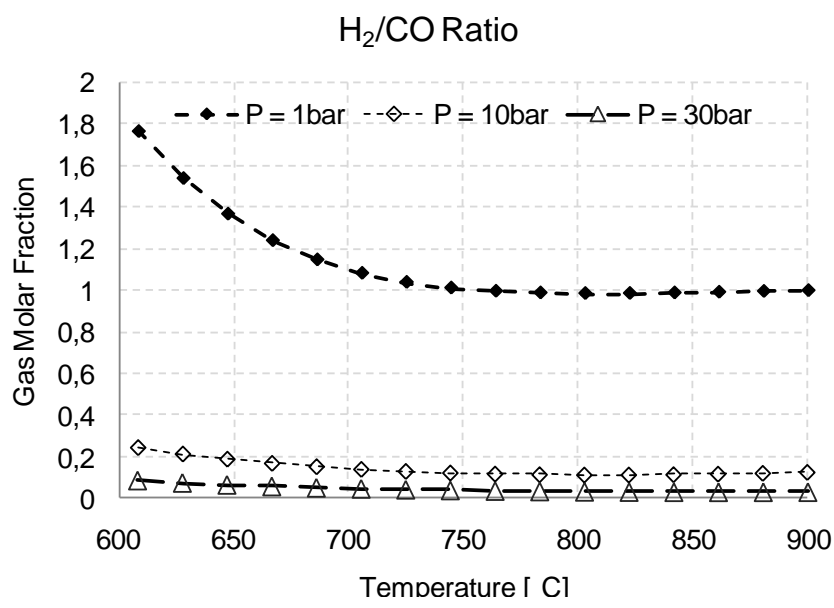

Figure 7. Hydrogen/carbon-monoxide molar fraction.

Figure 5 shows that the hydrogen content in the gas increases as the temperature is increased. Water vapour formation presents an opposite behaviour, decreasing as the temperature is increased. This is because hydrogen is consumed to form water vapour. The molar fraction methane decreases as the temperature increases. Figure 7 shows that the molar ratio hydrogen/carbon monoxide decreases as the temperature is increased. For the water gas shift reaction, as the temperature increases, it tends to shift towards reactants due to Le Chatelier's principle.

$$
\mathrm{CO}+\mathrm{H}_{2} \mathrm{O} \leftrightarrow \mathrm{CO}_{2}+\mathrm{H}_{2}
$$

For methane steam reforming,

$$
\mathrm{CH}_{4}+\mathrm{H}_{2} \mathrm{O} \leftrightarrow \mathrm{CO}+3 \mathrm{H}_{2}
$$

As temperature increases, the reaction tends toward the products. For low temperatures, the second reaction controls the process, reducing the amount of methane and water, and increasing hydrogen and carbon dioxide. At higher temperatures, the first reaction controls the process, decreasing carbon dioxide and hydrogen, and producing carbon monoxide and water. The hydrogen - carbon monoxide ratio decreases as the temperature increases, due to the combined effect of decreasing hydrogen and increasing carbon monoxide.

\subsection{Biomass to Methanol Conversion}

Figure 8 shows the process diagram for methanol production from syngas produced at the gasification stage. The most important processes involving changes in the composition of the syngas, such as reforming, water gas shift and methanol synthesis reactors are shown. The process is simulated considering the kinetic at the plug flow reactor and the removal of $\mathrm{CO} 2$ by mean of amine component separator. The refined methanol is obtained by a liquid methanol phase separator, and final refinement is done using a distillation column for biomethanol as a final product. 


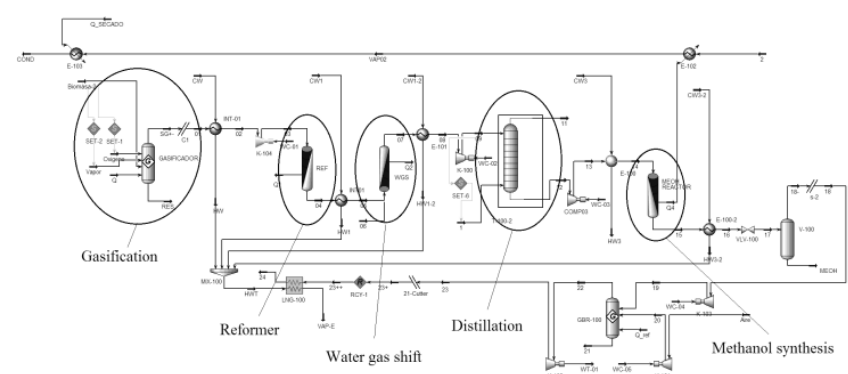

Figure 8. Biomethanol plant process.

Figure 9 presents the biomass to methanol yield. It is noticed that the amount of biomethanol obtained increases significantly as the temperature increases. Never the less, this affect is noticeable when the temperature reaches values over $800^{\circ} \mathrm{C}$. For pressure, the results show that a lower pressure the amount of methanol produced is greater than at high pressure.

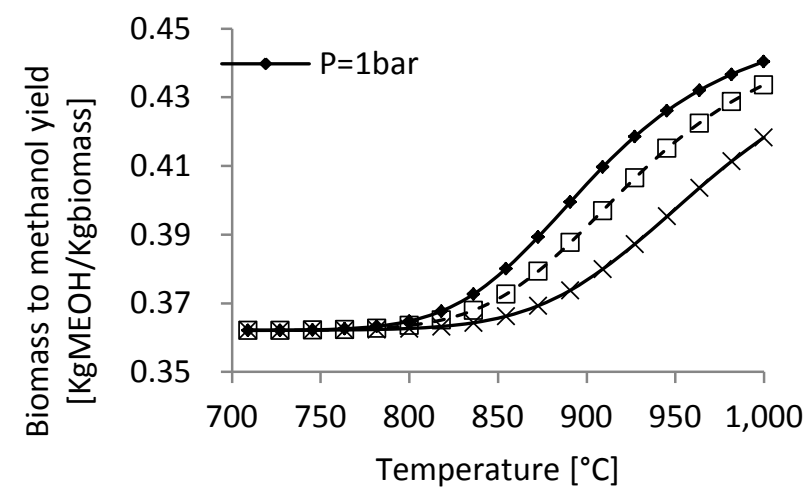

Figure 9. Biomass to Methanol yield for different temperatures.

\section{Conclusions}

The Palm oil biomass processing seems to be a feasible alternative for production of second generation biofuels. Obtaining syngas with the required conditions for catalytic synthesis from residual biomass processed in a fluidized bed with atmospheric air and water vapor presents a possible alternative. This analysis helps to decide which way the variables governing the process are supposed to be moved in order to attain the maximum values required, and how they affect the concentrations of the other gases. Never the less, this analysis needs to be complemented with transport equations considering heat and mass transfer in the reactor.

\section{Acknowledgements}

The authors want to acknowledge: Ministerio de Agricultura y Desarrollo Rural de Colombia (Convenio 054, Contrato 016-2008D3614- 3862) and COLCIENCIAS - UNINORTE (Contrato $\mathrm{N}^{\circ}$ 439-2007) for supporting this research.

\section{References}

Abdullah N. and Gerhauser H, (2008) Bio-oil derived from empty fruit bunches, Fuel, Vol. 87, No. 12, pp. 26062613.

Arrieta, F.R. Teixeira, F.N. and Yañez, E. (2007) Cogeneration potential in the Columbian palm oil industry, Biomass and Bioenergy, Vol. 31, No. 7, 503511.
Basu, P, (2006), Combustion and Gasification in Fluidized Beds, Taylor \& Francis Group

BTG biomass technology group BV, www.btgworld.com, 2008.

Bula, A., Mendoza, J., and Gómez, R. (2011) Syngas for Methanol Production from Palm Oil Biomass Residues Gasification. 24th International Conference on Efficiency, Cost, Optimization, Simulation and Environmental Impact of Energy System, ECOS 2011 Novi Sad, Serbia, July 4-7, 2011, PP. 3630-41

Chew T.L, Bhatia S, (2008), Catalytic processes towards the production of biofuels in a palm oil and oil palm biomass-based biorefinery, Bioresource Technology, Vol.99, No. 17, pp. $7911-7922$.

Ciferno, J.P and Marano, J. (2002) Benchmarking Biomass Gasification Technologies for Fuels, Chemicals and Hydrogen Production. U.S. Department of Energy National Energy Fedepalma (2006), La agroindustria de La Palma de aceite en Colombia y en el mundo, Anuario estadístico.

Cujia, G and Bula, A.(2010) Potencial Obtención de Gas de Síntesis para la Producción de metanol a partir de la Gasificación de Residuos de Palma Africana. Journal of Science and Technology of the Americas, Vol 35, No 2, pp. 106 - 112, February 2010.

Demirbas, A. (2002) Hydrogen Production from Biomass by the Gasifcation Process. Energy Sources, Vol. 24, No. 1, pp. 59-68.

Hernández, J, Aranda-Almansa, G., and Bula, A. (2010a) Gasification of biomass wastes in an entrained flow gasifier: Effect of the particle size and the residence time, Fuel Processing Technology, Vol 91, No 6, pp. 681-692.

Hernández, J, Aranda-Almansa, G., San Miguel, G. and Bula, A. (2010b) Gasification of Grapevine pruning waste in an entrained-flow reactor: Gas products, Energy efficiency and Gas conditioning alternatives. Global Nest Journal, Vol 12, No 2, pp. 215-227

Higman, C. and van der Burgt, M. (2003) Gasification, Elsevier Science (USA).

Husain Z, Zaina Z.A, (2003), Analysis of biomass-residuebased cogeneration system in palm oil mills, Biomass and Bioenergy, Vol. 24, No. 2, pp. $117-124$

Kelly-Yong, T.L., and Lee, K.T. (2007) Potential of hydrogen from oil palm biomass as a source of renewable energy worldwide. Energy Policy, Vol. 35, No. 11, pp. 5692-5701.

Kirubakaran V, et al. (2007) A review on gasification of biomass. Renew Sustain Energy Review, Vol. 13, no. 1, pp. 176-186.

Li, X.T. and Grace, J.R.. (2003) Biomass gasifcation in a circulating fluidized bed. Biomass and Bioenergy, Vol. 26, No. 2, pp. 171-193.

Milne T.A, and Evans R.J, (1998), Biomass Gasifier "Tars":Their Nature, Formation, and Conversion, National Renewable Energy Laboratory, NREL/TP$570-25357$ 
Minteer S, (2006), Alcoholic Fuels, CRC Press Taylor \& Francis Group.

Quaak, P. Knoef, H. and Stassen, H. (1999) Energy from Biomass, World Bank Publication.

Yan, R., Yang, H., Chin, T., and Liang, D. (2005) Influence of temperature on the distribution of gaseous products from pyrolyzing palm oil wastes. Combustion and Flame, Vol. 142, pp. 24-32.

Hanping Chen a, Chuguang ZhengSaxena, R.C. (2008) Thermo-chemical routes for hydrogen rich gas from biomass: A review. Renewable and Sustainable Energy
Reviews, Vol. 12, No. 7, pp. 1909-1927.

Sumathi S, Chaia, S.P. and Mohamed A.R. (2007), Utilization of oil palm as a source of renewable energy in Malaysia. Renewable and Sustainable Energy Reviews, Vol. 12, No. 9, pp. 2404-2421.

U.S. Department of Energy, Handbook of biomass Downdraft gasifier engine system, Solar Technical Information Program, 1988.

Yusoff S, (2006), Renewable energy from palm oil innovation on effective utilization of waste, Journal of Cleaner Production, Vol. 14. No. 1, pp. 87 - 93. 